\title{
Elaboration of modified starch-based film from yam variety espino (dioscorearotundata) for use in food packaging
}

\author{
Ana María Fortich Fortich ${ }^{\# 1}$, Gladis Victoria Pájaro Padilla \\ Deniles De Arco Rosano ${ }^{\#}$, Diofanor Acevedo Correa ${ }^{* 2}$
}

${ }^{\#}$ Faculty of Pharmaceutical Sciences, Research Group Research Group on Pharmaceutical, Cosmetic and Food Technology GITFCA, Universidad de Cartagena, Cl. 6 \#3"N, Cartagena de Indias, Bolívar.

*Faculty of Food Engineering, School of Engineering, Research Group NutriciónSalud y Calidad Alimentaria (NUSCA), Universidad de Cartagena, Av. El Consulado, St. 30 No. 48-152. Cartagena de Indias 1deniles1959@yahoo.es; ${ }^{2}$ dacevedoc1@unicartagena.edu.co

\begin{abstract}
The aim of this research was to produce a modified starch-based film of the buckthorn yam variety (diocorearotundata) for use in food packaging. Native starch was first obtained, then the starch was chemically modified and a qualitative and quantitative determination of acetyl groups and substitution grade was made. film formulation was also optimized and the physical and mechanical characteristics of each of the films obtained were evaluated to select the formulation to be used. Finally, it was applied in a sausage type meat sausage. The slice of sausage used for coating with the control and autochthonous film showed greater weight loss compared to slices covered with modified starch. The slice of sausage used for coating with the control and native film showed higher losses compared to the slices covered with modified starch. The film made by modification can be promising for use in meat products.
\end{abstract}

\section{INTRODUCTION}

Limited fossil fuel reserves and the environmental impact caused by the use of non-biodegradable plastic containers have led to the use of biopolymers recognized as safe for human consumption, such as starches, cellulose derivatives, chitosan/chitin, gums or plant-based proteins. These materials offer the possibility of thin films and coatings to cover fresh or processed foods for extended shelf life [1]. Starch is an abundant, economical and naturally renewable polysaccharide, which is widely applied in various areas of polymer science, it has been successfully used in the packaging industry and is readily biodegradable in soil. However, native starch has several disadvantages such as processability and poor solubility in common organic solvents that limit its broad applications. Chemical modifications of starch, including esterification, are effective methods for improving the properties of starch. Acetylated starch is a starch ester that has been studied over the past two decades [2]. Chi et al.,[3] used FTIR to detect the structure of acetylated starches, reporting a substitution degree (SD) of $0.85,1.78$ and 2.89. The FTIR spectra of different DS of acetylated starch showed some new absorption bands at 1754,1435 and $1240 \mathrm{~cm}^{-1}$ assigned to carbonyl $\mathrm{C}=\mathrm{O}, \mathrm{CH}_{3}$ anti-symmetric deformation vibration and carbonyl $\mathrm{C}-\mathrm{O}$ stretch vibration. These new absorptions suggest that acetylated starch products formed during the esterification process. With the esterification process, acetyl groups were introduced into starch, proton resonances of anhydroglucose unit showed some changes compared to native starch.

The modified starch, part of the hydroxyl groups in units of anhydroglucose are converted into acetyl groups. Acetylated 0.01-0.2 starch low (DS) has been applied in many areas, such as film formation, bonding, adhesion, thickening, stabilization and texturing. Acetylated starch with low DS is commonly obtained by esterification of native starch with acetic anhydride in an aqueous medium in the presence of an alkaline catalyst [4]. The inserted acetyl groups cause a reorganization of the starch at a structural level through the steric impediment. When acetyl groups are incorporated into the starch molecule, their mutual repulsive effect is observed, facilitating the penetration of water molecules into newly formed amorphous areas [5]. Studies on starch acetylation indicate an increase in solubility and water absorption, and the presence of acetyl groups makes gelatinisation and the formation of an orderly structure difficult, and delays the retrogradation of starch [6].

Starch modified by esterification has been reported to form intermolecular links between hydroxyl groups in the crosslinking process. Kaur et al., [7] demonstrated that substitution of hydroxyl groups by acetyl groups in the starch structure prevents parallel orientation of starch chains initiating retrogradation. The presence of acetyl groups also leads to delayed amylopectin crystallization and water retention in starch molecules. These results confirm the findings reported by Pietrzyk et al., [4] in which low oxidized corn starch was also more susceptible to acetylation compared with waxy corn starch because it contained more acetyl groups than corn starch at the same oxidation levels. Since the content of carboxyl and acetyl groups in the resulting modified starches was 
less than $1.3 \%$ and $2.5 \%$ respectively, these starches are suitable for use in the food industry [8]. In view of the above, the aim of this research was to elaborate a modified starch-based film from yam variety Espino(diocorearotundata) for possible use in food packaging.

\section{MATERIALS AND METHODS}

A. Obtaining the raw material

The tuber of yam variety Espino (Dioscorearotundata) was purchased in the city of Cartagena de India in the local market named Bazurto. The starch was obtained in the laboratory of the GITFCA group for later modification. The plant material was chosen in July 2017 in which it was found fresh, whole, with the appropriate sensory characteristics, in a state of maturity for consumption. All these tests were carried out in the laboratories of Bromatology and Pharmacotecnia of the Faculty of Pharmaceutical Sciences of the University of Cartagena.

\section{B. Starch extraction process from yam variety Espino}

The starch was obtained using $20 \mathrm{~kg}$ of healthy Dioscorearotundata tubers, selected according to the selection criteria. Once the material was acquired, the process of obtaining the starch began as follows: the whole yams were washed in order to remove adhering impurities. Afterwards, peeling was carried out and cut into pieces, liquefied with drinking water until a white solution was obtained, filtered with a cloth and the filtrate was left to rest and then decanted, the supernatant was removed. The process was repeated until the supernatant water was clear after decanting. When this happened, one last wash was done for three hours. The sediment was washed with deionized water, vacuum filtered and dried in trays at $55^{\circ} \mathrm{C}$ for $12 \mathrm{~h}$, then ground and stored in airtight containers [9], the starch yield was $10 \%$.

\section{Chemical modification of native starch}

Starch acetylation process: $50 \mathrm{~g}$ of native starch was weighed and $250 \mathrm{~mL}$ of distilled water was added, making a uniform suspension aided by a magnetic stirrer to maintain a steady suspension. The $\mathrm{pH}$ of the sample was adjusted with a few drops of $\mathrm{NaOH}$ to $3 \%$, which acts as a catalyst and was left at an initial $\mathrm{pH}$ between 8 and 8.5. Then acetic anhydride was added, adjusting the $\mathrm{pH}$ between 8 and 8.5 with $\mathrm{NaOH}$ to $3 \%$ until adding the chosen volume of acetic anhydride (volumes between $2 \mathrm{~mL}, 4 \mathrm{~mL}$ and $8 \mathrm{~mL}$ were used to obtain different levels of substitution), after this the system was left reacting for $10 \mathrm{~min}$. After this time the reaction was stopped with $0.5 \mathrm{~N} \mathrm{HCl}$ and the starch was washed (three successive washes and three vacuum filtered). Later it was dried in a tray oven at $50^{\circ} \mathrm{C}$ by $24 \mathrm{~h}$ and crushed with a mortar $[10 ; 11]$.

Qualitative and quantitative determination of acetyl groups: The measurement of the acetyl content was based on titration of the acetyl residues after the sample was subjected to an alkaline treatment. Weighed $1 \mathrm{~g}$ of acetylated starch (dry basis) into a $250 \mathrm{ml}$ erlenmeyer, added $50 \mathrm{ml}$ of $75 \%$ ethanol solution, lightly capped and placed in a water bath at $50{ }^{\circ} \mathrm{C}$ with stirring for $30 \mathrm{~min}$. It was allowed to cool and $20 \mathrm{~mL}$ of $0.5 \mathrm{~N} \mathrm{KOH}$ was added during stirring. The flask was covered and preserved for $72 \mathrm{~h}$ with possible agitation.After $72 \mathrm{~h}$, the saponified sample was titrated with $\mathrm{HCl} 0.5 \mathrm{~N}$ using phenolphthalein as an indicator, left to stand for 2 hours, then titrated the additional alkali that may have leached from the sample. The same procedure was performed on native starch for reference $[12 ; 13]$. The percentage of acetyl groups was calculated using the following formula: $\operatorname{acetyl}(\%)=\frac{B-M * N * 0.043}{\text { sample }(g)} * 100$

Where: $\mathrm{B}=\mathrm{HCl}$ spent on the control sample $(\mathrm{mL}) ; \mathrm{M}=\mathrm{M}=\mathrm{HCl}$ spent on the sample $(\mathrm{mL}) ; \mathrm{N}=\mathrm{HCl}$ normality; $\mathrm{Pm}=$ Sample weight $(\mathrm{g}) ; 0.043=$ milliequivalents of acetyl group.

Determination of the substitution Degree (SD): The substitution degree (SD) of acetylated starch is equivalent to the average number of $\mathrm{OH}$ groups replaced by acetyl groups $\left(\mathrm{CH}_{3}-\mathrm{C}=\mathrm{O}\right)$ in the glucose anhydrous unit (GAU) and calculated using the following formula:

$S D=\frac{162 * \text { acetyl }(\%)}{4300-(42 * \% \text { acetyl })}$

$162=$ molecular weight of GAU; $4300=100 \times$ molecular weight of acetyl group; 42= (molecular weight of acetyl group - 1).

Production of the film: The elaboration process the film was based on the methodology proposed by Avendaño[14], using the thermal gelatinisation method. The raw materials were first weighed, then the components were mixed, followed by heating with steady mechanical stirring. It was then molded and cooled with steady agitation, finally cut and conditioned. 


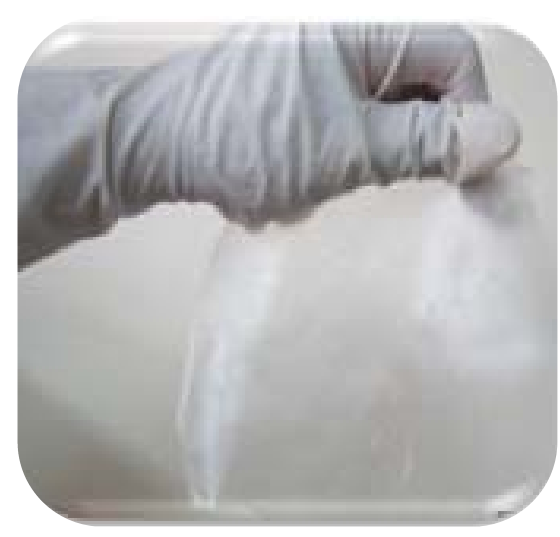

Figure 1. Film made from yam starch

\section{Mechanicaltesting of the film}

Water vapour permeability: In order to determine the water vapour permeability, Colombian Technical Standard NTC 499 - $501[15,16,17]$ and International ASTM E 96-80 were taken into account asreference following the procedure described in the investigation carried out by Avendaño[14] with some modifications, conditioned at $\left(10^{\circ} \mathrm{C}, 40^{\circ} \mathrm{C}\right.$ and $\left.25^{\circ} \mathrm{C}\right)$ and a relative humidity gradient of $(0$ to $70 \%, 0$ to $80 \%$ and 0 to $50 \%)$, respectively.

Tensile strength: It was determined to the films from the permeation test. These were cut in the form of a specimen with their corresponding dimensions as specified in the Colombian Technical Standard NTC [16] 500.

E. Application of the film to assess its protection against dehydration

In order to evaluate the protective capacity of the films against dehydration, they were applied to a sausage sausage meat derivative. Five samples were coated with a native starch film, five samples were coated with modified starch film and five unfilmed samples taken as control, for a total of 15 slices. All samples were stored refrigerated for a period of 15 days and weighed daily to see if the film protected the food from dehydration. The determination of the protective capacity of the film was made by weight difference and applying the following formula:

Moisture loss $(\%)=\frac{(I W-F W)}{I W} * 100$

Where: IW is the initial weight of the sample before coating and FW is the final weight of the sample.

\section{Data analysis}

All measurements were carried out in triplicate. Variance analysis (ANOVA) was performed using Duncan's multiple-range tests to compare the mean of treatments. La significancia se definió en $p<0.05$, El análisis de los datos se realizó en el programa estadístico Statgraphic Centurión, versión 16.2.04.

\section{RESULTS AND DISCUSSION}

\section{A. Determination of acetyl groups $(\mathrm{CH}-\mathrm{C}=\mathrm{O})$ and substitution degree}

Table 1 shows that as the $\mathrm{mL}$ of acetic anhydride increased, the percentage of acetyl groups also increased, being different with the ratio of $\mathrm{mL}$ of $\mathrm{HCl}$ that decreased these groups with lower content of this acid. Similarly, the substitution degree for all acetylated starches in this study was directly related to the volume of acetic acid used, so that it increased as the volume of acid augmented. This can be attributed in large part to the partial depolymerization of starch chains and the weakening of the structure of the starch granule due to oxidation, facilitating the penetration of the reagent into the granules [4]. These data were consistent with claims by Khalil et al., [18] who showed that susceptibility to acetylation decreases with increasing oxidation level of starch, but increases for starches subjected to prior hydrolysis. Gunaratne and Corke[19] found that the starch acetylation degree decreases with the acid hydrolysis degree. They claimed that the degradation of amylose and amylopectin and the realignment and self-association of starch macromolecules during acid treatment could reduce the reaction sites for acetylation.Pietrzyk et al., [20] indicated that at the same oxidation levels, native corn starch was characterized by a higher content of carboxyl groups compared to waxy starch. This phenomenon could be the result of different amylose contents of these starches. According to the FDA, the maximum SD allowed for food use is 0.09 , therefore the ranges obtained in the study are within normal values, except those presented for starch modified with $8 \mathrm{~mL}$ acetic anhydride, which makes it unfit for human consumption (FDA). 
Table 1. Results in acetyl groups (\%) and yam starch substitution degrees

\begin{tabular}{ccccc}
\hline $\begin{array}{c}\text { Acetic anhydride } \\
(\mathbf{m L})\end{array}$ & $\begin{array}{c}\text { Weight sample } \\
\mathbf{( g )}\end{array}$ & $\mathbf{H C l}(\mathbf{m L})$ & $\begin{array}{c}\text { Acetyl groups } \\
(\mathbf{\%})\end{array}$ & SD \\
\hline $2 \mathrm{~mL}$ & $1.045 \pm 0.034$ & $16.13 \pm 0.15$ & $1.133 \pm 0.11$ & $0.041 \pm 0.004$ \\
$4 \mathrm{~mL}$ & $1.255 \pm 0.19$ & $14.2 \pm 0.36$ & $2.224 \pm 0.093$ & $0.086 \pm 0.004$ \\
$8 \mathrm{~mL}$ & $1.078 \pm 0.055$ & $12.43 \pm 0.40$ & $3.985 \pm 0.18$ & $0.156 \pm 0.007$ \\
Native & $1.086 \pm 0.045$ & $17.43 \pm 0.057$ & $0.0 \pm 0.0$ & $0.0 \pm 0.0$ \\
\hline
\end{tabular}

B. Production of the film

Once the starch was obtained and selected, the film was made with the optimized formulation of native and modified starch as shown in Table 2. The necessary methodology for the preparation of these was developed, adjusting mixing times for the formation of emulsions, as well as the necessary conditions for drying and obtaining the samples.

Table 2.Optimization of film formulation from native starch

\begin{tabular}{cccccc}
\hline $\mathbf{N}^{\circ}$ & \multicolumn{3}{c}{ Sample } & $\mathbf{T}^{\circ}$-Time & Characteristics,appearance \\
\cline { 2 - 3 } & Starch $(\mathrm{g})$ & Glycerol $(\mathrm{mL})$ & Water $(\mathrm{mL})$ & & Broken, white. \\
1 & 13 & 10 & 77 & $65^{\circ} \mathrm{C} 35 \mathrm{~min}$ & Broken, white. \\
2 & 13 & 30 & 57 & $70^{\circ} \mathrm{C} 20 \mathrm{~min}$ & Fragile, brittle \\
3 & 30 & 30 & 40 & $80^{\circ} \mathrm{C} 33 \mathrm{~min}$ & Hard, not elastic \\
4 & 26 & 20 & 54 & $80^{\circ} \mathrm{C} 30 \mathrm{~min}$ & Clear, elastic \\
5 & 7 & 5 & 38 & $85^{\circ} \mathrm{C} 15 \mathrm{~min}$ & Clear, elastic \\
6 & 7 & 5 & 38 & $85^{\circ} \mathrm{C} 15 \mathrm{~min}$ & Clear, elastic \\
7 & 7 & 5 & 38 & $85^{\circ} \mathrm{C} 15 \mathrm{~min}$ & \\
\hline
\end{tabular}

Table 3 shows the optimum formulation of the modified starch film. A film with suitable characteristics was achieved to be used in tension, elongation and permeability tests. It was established that the proportions used in native starch film were the same as modified starch.

Table 3.Optimization of film formulation with modified starch

\begin{tabular}{cccccc}
\hline $\mathbf{N}^{\circ}$ & \multicolumn{3}{c}{ Sample } & $\mathbf{T}^{\circ}$-Time & $\begin{array}{c}\text { Characteristics, } \\
\text { appearance }\end{array}$ \\
\cline { 2 - 4 } 1 & Starch $(\mathrm{g})$ & Glycerol $(\mathrm{mL})$ & Water $(\mathrm{mL})$ & & \\
\hline
\end{tabular}

The concentrations of plasticiser in this case glycerin have been investigated. Plasticisers give you the flexibility to be added, generally increase the permeability of them, as they reduce intermolecular forces between polymer chains and increase the free volume, therefore there is more space for water molecules to migrate, in addition hydrophilic plasticisers such as glycerol are compatible with the polymeric material that forms the film and increase the absorption capacity of molecules.

C. Permeability of the edible film

The films are exposed to different stresses during packaging and conditioning of food matrices, mechanical properties such as tensile strength and elongation are important parameters to evaluate in order to select the ideal components for processing. The permeability values were different from other types of films, this can be attributed to the source of the hydrocolloid, the thickness and the differences in the process of elaboration and analysis [21]. Gonzáles et al., [22] reported that water vapour permeability values of binary carboxymethyl cellulose and xanthan gum biofilms increased significantly as the addition of low-acillusgelatine gum increased. Such behaviour may be due to the influence of crosslinking reactions on the moisture diffusion coefficient within the polymer network, indicating structural changes in the polymer matrix.

Table 4. Permeability test data carried out in the furnace

\begin{tabular}{ccccccccccc}
\hline $\begin{array}{c}\text { Type of } \\
\text { film }\end{array}$ & $\begin{array}{c}\mathbf{8 : 0 0} \\
\text { am }\end{array}$ & $\begin{array}{c}\mathbf{9 : 0 0} \\
\text { am }\end{array}$ & $\begin{array}{c}\mathbf{1 0 : 0 0} \\
\text { am }\end{array}$ & $\begin{array}{c}\mathbf{1 1 : 0 0} \\
\text { am }\end{array}$ & $\begin{array}{c}\mathbf{1 2 : 0 0} \\
\text { am }\end{array}$ & $\begin{array}{c}\mathbf{1 : 0 0} \\
\text { pm }\end{array}$ & $\begin{array}{c}\mathbf{2 : 0 0} \\
\text { pm }\end{array}$ & $\begin{array}{c}3: 00 \\
\text { pm }\end{array}$ & $\begin{array}{c}\mathbf{4 : 0 0} \\
\text { pm }\end{array}$ & $\begin{array}{c}5: 00 \\
\text { pm }\end{array}$ \\
\hline Native 1 & 83.75 & 83.71 & 83.67 & 83.59 & 83.56 & 83.52 & 83.48 & 83.45 & 83.43 & 83.40 \\
Native 2 & 94.58 & 94.55 & 94.53 & 94.49 & 94.43 & 94.38 & 94.32 & 94.26 & 94.15 & 94.01 \\
Modified1 & 83.12 & 83.10 & 83.06 & 83.03 & 82.98 & 82.96 & 82.94 & 82.92 & 82.91 & 82.88 \\
Modified 2 & 86.71 & 86.68 & 86.65 & 86.63 & 86.58 & 86.55 & 86.54 & 86.51 & 86.49 & 86.44 \\
\hline
\end{tabular}




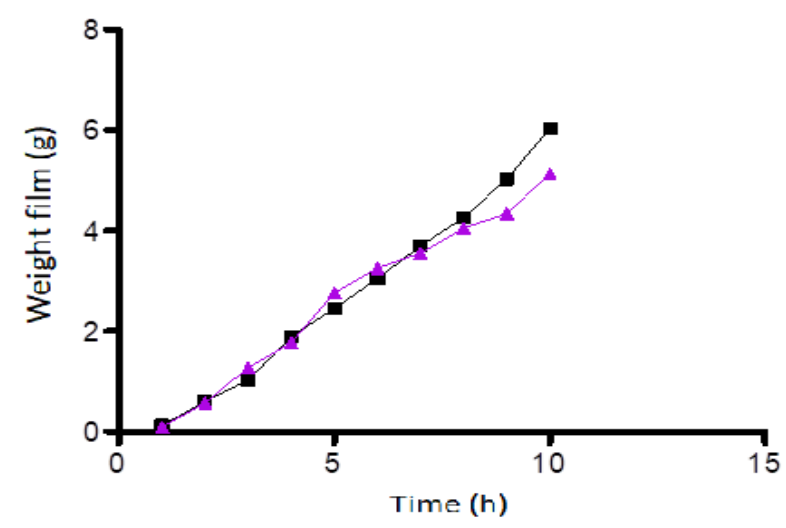

Figure 2. Moisture loss in the oven for $(-\boldsymbol{t})$ native and $\left(\boldsymbol{t}^{-}\right)$modified starch.

Table 5. Data from the permeability test carried out in the refrigerator

\begin{tabular}{ccccccccccc}
\hline $\begin{array}{c}\text { Type of } \\
\text { film }\end{array}$ & $\begin{array}{c}8: 00 \\
\mathrm{am}\end{array}$ & $\begin{array}{c}9: 00 \\
\mathrm{am}\end{array}$ & $\begin{array}{c}10: 00 \\
\mathrm{am}\end{array}$ & $\begin{array}{c}11: 00 \\
\mathrm{am}\end{array}$ & $\begin{array}{c}12: 00 \\
\mathrm{am}\end{array}$ & $\begin{array}{c}1: 00 \\
\mathrm{pm}\end{array}$ & $\begin{array}{c}2: 00 \\
\mathrm{pm}\end{array}$ & $\begin{array}{c}3: 00 \\
\mathrm{pm}\end{array}$ & $\begin{array}{c}4: 00 \\
\mathrm{pm}\end{array}$ & $\begin{array}{c}5: 00 \\
\mathrm{pm}\end{array}$ \\
\hline Native 1 & 64.11 & 64.19 & 64.21 & 64.23 & 64.27 & 64.30 & 64.32 & 64.35 & 64.52 & 64.65 \\
Native 2 & 68.32 & 68.39 & 68.43 & 68.46 & 68.50 & 68.53 & 68.56 & 68.59 & 68.61 & 68.64 \\
Modified1 & 64.23 & 64.31 & 64.33 & 64.37 & 64.42 & 64.47 & 64.53 & 64.61 & 64.69 & 64.78 \\
Modified 2 & 68.51 & 68.53 & 68.55 & 68.59 & 68.60 & 68.63 & 68.69 & 68.85 & 68.96 & 69.12 \\
\hline
\end{tabular}

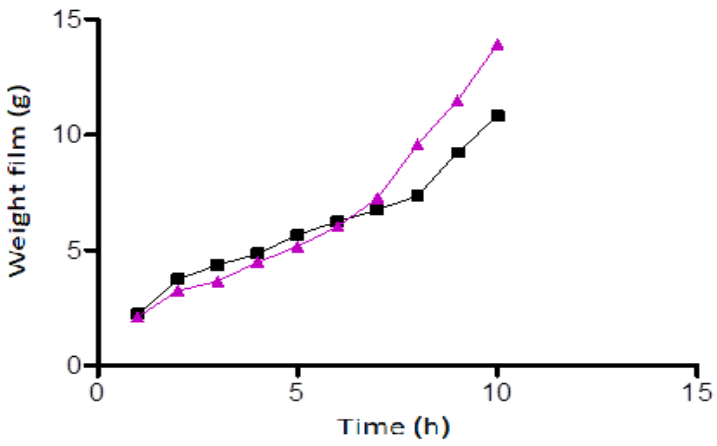

Figure 3. Moisture loss in the refrigerator for $(-\boldsymbol{-})$ native and $\left(\boldsymbol{t}^{-}\right)$modified starch.

Table 6. Permeability test data at room temperature

\begin{tabular}{ccccccccccc}
\hline $\begin{array}{c}\text { Type of } \\
\text { film }\end{array}$ & $\begin{array}{c}\mathbf{8 : 0 0} \\
\text { am }\end{array}$ & $\begin{array}{c}\mathbf{9 : 0 0} \\
\text { am }\end{array}$ & $\begin{array}{c}\mathbf{1 0 : 0 0} \\
\text { am }\end{array}$ & $\begin{array}{c}\mathbf{1 1 : 0 0} \\
\text { am }\end{array}$ & $\begin{array}{c}\mathbf{1 2 : 0 0} \\
\text { am }\end{array}$ & $\begin{array}{c}\mathbf{1 : 0 0} \\
\text { pm }\end{array}$ & $\begin{array}{c}\mathbf{2 : 0 0} \\
\text { pm }\end{array}$ & $\begin{array}{c}\text { 3:00 } \\
\text { pm }\end{array}$ & $\begin{array}{c}4: 00 \\
\text { pm }\end{array}$ & $\begin{array}{c}5: 00 \\
\text { pm }\end{array}$ \\
\hline Native 1 & 64.701 & 64.752 & 64.846 & 64.998 & 65.053 & 65.098 & 65.142 & 65.189 & 65.221 & 65.249 \\
Native 2 & 63.854 & 63.937 & 64.001 & 64.1098 & 64.198 & 64.223 & 64.298 & 64.321 & 64.410 & 64.452 \\
Modified1 & 68.663 & 68.726 & 68.920 & 69.00 & 69.022 & 69.124 & 69.210 & 69.290 & 69.300 & 69.327 \\
Modified 2 & 63.367 & 63.401 & 63.485 & 63.51 & 63.556 & 63.590 & 63.612 & 63.675 & 63.712 & 63.737 \\
\hline
\end{tabular}




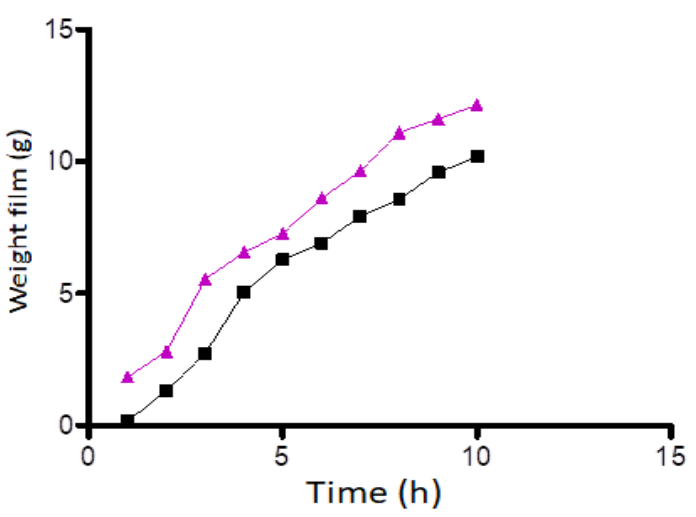

Figure 4. Moisture loss at room temperature for $\left(\boldsymbol{t}^{-}\right)$native and $\left(\boldsymbol{t}^{-}\right)$) modified starch.

In all tested conditions of starch, glycerol and water films, it was demostrated that the permeability of hydrophilic films is directly related to humidity and temperature. Polysaccharides generate films that are not a good barrier to water vapor because of their hydrophilic nature [23]. However, this feature allows water vapor to move through the film, preventing condensation, which can be a potential source of microbial spoilage in fruits and vegetables. Baron et al., [24] obtained films based on mixtures of chitosan and pectin. They indicated that the higher chitosan content used in film formulations produced a significant decrease $(p<0.05)$ in moisture content compared to the higher pectin content. Pure pectin-based films showed the highest solubility in water, mainly caused by the absorption of water during hydration of the polymer matrix, due to the high hydrophobicity of this low molecular weight biopolymer.

D. Tensile strength

The mechanical properties of films are as important as the barrier properties. Tensile strength gives a measure of the integrity and durability of films for potential applications and the elongation percentage is a measure that represents the stretch properties of the films. The Table 7 shows that as tension increased, the final length of the film increased, being higher in all cases with modified starch, which was also reflected in the elongation percentage of, which increased by more than $200 \%$ in all cases analyzed. These changes may have been due to the formation of new functional groups (carboxyl and acetyl groups) in amylopectin during the modification, which caused hydrogen bonds in starch to strengthen, facilitating water penetration into the granules [25]. Gonzalez et al., [22] reported that the stress resistance (RT) of control biofilms showed lower RT values, increasing as low-acillusgelana concentrations were higher, possibly to increased crosslinking reactions. The higher RT values $(25.02 \mathrm{MPa}$ ) were obtained in the film with $0.7 \%$ low-acillus gel gum. This may be possible to the different structures of each hydrocolloid, which forms firm but brittle gels to come into contact with mono or divalent cations.

Table 7. Results of tensile strength analysis

\begin{tabular}{ccccccccccc}
\hline & $\begin{array}{c}\text { Film } \\
\text { with } \\
\text { native } \\
\text { starch }\end{array}$ & $\begin{array}{c}\text { Film } \\
\text { with } \\
\text { modified } \\
\text { starch }\end{array}$ & $\begin{array}{c}\text { Film } \\
\text { with } \\
\text { native } \\
\text { starch }\end{array}$ & $\begin{array}{c}\text { Film } \\
\text { with } \\
\text { modified } \\
\text { starch }\end{array}$ & $\begin{array}{c}\text { Film } \\
\text { with } \\
\text { native } \\
\text { starch }\end{array}$ & $\begin{array}{c}\text { Film } \\
\text { with } \\
\text { modified } \\
\text { starch }\end{array}$ & $\begin{array}{c}\text { Film } \\
\text { with } \\
\text { native } \\
\text { starch }\end{array}$ & $\begin{array}{c}\text { Film } \\
\text { with } \\
\text { modified } \\
\text { starch }\end{array}$ & $\begin{array}{c}\text { Film } \\
\text { with } \\
\text { native } \\
\text { starch }\end{array}$ & $\begin{array}{c}\text { Film } \\
\text { with } \\
\text { modified } \\
\text { starch }\end{array}$ \\
\hline $\begin{array}{c}\text { Tensile N } \\
\text { (gr) }\end{array}$ & 36 & 36 & 74 & 74 & 92 & 92 & 120 & 120 & 200 & 200 \\
$\begin{array}{c}\text { Long. Initial } \\
\text { (cm) }\end{array}$ & 3 & 3 & 3 & 3 & 3 & 3 & 3 & 3 & 3 & 3 \\
$\begin{array}{c}\text { Long. Final } \\
\text { (cm) }\end{array}$ & 3.13 & 3,15 & 3.4 & 3.76 & 3.33 & 3.93 & 3.53 & 4.36 & 3.6 & 5.03 \\
$\begin{array}{c}\text { L= Lf-Lo } \\
\text { Elongation } \\
\text { (\%) }\end{array}$ & 0.13 & 0,1 & 0.4 & 0.76 & 0.33 & 0.93 & 0.53 & 1.36 & 0.6 & 2.03 \\
\hline
\end{tabular}


The elongation or elasticity of the films is the distance $(\mathrm{mm})$ that the film can stretch before breaking, in this investigation the modified starch based film generated films with a higher elongation than native starch based films. The different retrogradation processes are mainly due to the absorption of water inside the thermoplastic matrix, which allows the rearrangement of polymer chains thanks to the presence of $\mathrm{OH}$ groups. Retrogradation then affects mechanical properties, stress increases and elongation decreases affecting the quality of bioplastics[14], this was one of the most relevant properties that was improved at the time of starch modification. Similar results obtained by Fuentes et al., [26], showed that by increasing the concentrations of low-acillusgelanarubber significantly increased the tensile strength and elongation at break values, which is due to the increase in molecular interactions, thus increasing the cohesive strength of biofilms.

\section{E. Weight loss percentage}

Weight loss was expressed as a percentage of moisture loss compared to the initial product weight. All samples including the control showed progressive weight loss during storage. La rodaja de salchichón control y nativo presentó pérdidas superiores comparándolas con las rodajas cubiertas con almidón modificado, en este caso el recubrimientos pudo actuar como "agentes sacrificadores" retardando la pérdida de humedad de las rodajas de salchichón al agregar humedad adicional en la superficie que se pierde primero [27].

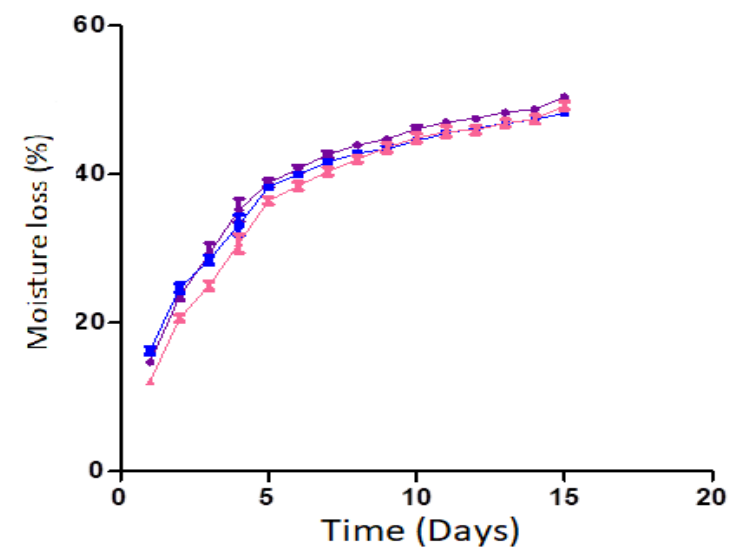

Figure 5. Moisture loss percentage of coated samples with ( $\bullet-$ ) native starch film, $(\longrightarrow-)$ ) modified starch film and $(\longrightarrow-)$ ) unfilmed.

\section{CONCLUSIONS}

As the milliliters of acetic anhydride increased, the percentage of acetyl groups also increased, being different with the ratio of milliliters of $\mathrm{HCl}$ decreasing these groups with lower content of this acid. The substitution degree for all acetylated starches in this study was directly related to the volume of acetic acid used, so that it increased as the volume of acid increased. The chemical modification (acetylation) of starches produced important changes for film formation, such as elongation compared to its native form. The slice of sausage used for coating with the control and native film showed higher losses compared to the slices covered with modified starch. The film made by modification can be promising for use in meat products.

\section{REFERENCES}

[1] M. Z. Elsabee and E. S Abdou, "Chitosan based edible films and coatings: A review", Materials Science and Engineering, vol. 33 , no. 4, pp. 1819-1841, 2013.

[2] Y. J. Wang and L. Wang, "Characterization of Acetylated Waxy Maize Starches Prepared under Catalysis by Different Alkali and Alkaline-Earth Hydroxides", Starch-Stärke, vol. 54, no. 1, pp. 25-30. 2002.

[3] H. Chi, K. Xu, X. Wu, Q. Chen, D. Xue, C. Song andP. Wang, "Effect of acetylation on the properties of corn starch",Food Chemistry, vol. 106, no. 3, pp. 923-928, 2008.

[4] S. Pietrzyk, L. Juszczak, T. Fortuna andA. Ciemniewska, "Effect of the oxidation level of corn starch on its acetylation and physicochemical and rheological properties",Journal of Food Engineering, vol. 120, pp. 50-56, 2014.

[5] O. S. Lawal, K. O. Adebowale andR. A. Oderinde, "Functional properties of amylopectin and amylose fractions isolated from bambarra groundnut (Voandzeia subterranean) starch”,African journal of Biotechnology, vol. 3, no. 8, pp. 399-404, 2004.

[6] M. Włodarczyk-Stasiak, A. Mazurek, R. Kowalski, U. Pankiewicz andJ. Jamroz,"Physicochemical properties of waxy corn starch after three-stage modification",Food Hydrocolloids, vol. 62, pp. 182-190, 2017.

[7] L. Kaur, N. Singh andJ. Singh, "Factors influencing the properties of hydroxypropylated potato starches",Carbohydrate Polymers, vol. 55, no. 2, pp. 211-223, 2004.

[8] Commission Regulation (EU) No 231/2012 of 9 March 2012, laying down specifications for food additives listed Annexes II and III to Regulation (EC) No 1333/2008 of the European Parliament and of the Council. OfficialJournal of theEuropean L 83/1.

[9] L. Tejeda, C. Tejada, A. Villabona, A. Tarón, R. Barrios, L.M. Tejeda, "Aprovechamiento del ñame espino (Dioscorearotundata) en la producción de bioplásticos", Consultada el 15 de febrero del 2017, 2007.

[10] L. Bello, S. Contreras, S. Romero, J. Solorza, A. Jiménez,"Propiedades químicas y funcionales del almidón modificado de plátano Musa paradisiaca 1. (var. macho)",Agrociencia, vol. 36, pp. 169-180,2002.

[11] N. Singh andS. Singh, "Characteristics of acetylated starches prepared using starches separated from different rice cultivars", Journal of Food Engineering, vol. 70, pp. 117-127, 2005. 
[12] H. Chi, K. Xu, X. Wua, Q. Chen, D. Xue, C. Song, W. Zhang, P. Wang, "Effect of acetylation on the properties of corn starch", Food Chemistry, vol. 106, pp. 923-928, 2008.

[13] D. Phillips, J. Xing, H. Liu, D. Pan, H. Corke, "Potential Use of Raman Spectroscopy for Determination of Amylose Content in Maize Starch", Cereal Chemistry,vol. 76, no. 5, pp. 821-823, 1999.

[14] G. Avendaño, "Diseño y evaluación de las propiedades mecánicos y de barrera de un biopolímero obtenido a partir del almidón de papa para ser empleado en empaques para alimentos", Universidad Nacional abierta y a distancia (UNAD). 2009.

[15] NTC 499, "Norma Técnica Colombiana "Películas de Celulosa Regenerada. Especificaciones".

[16] NTC 500, "Norma Técnica Colombiana "Películas de celulosa Regenerada. Determinación de las propiedades de tensión".

[17] NTC 501, "Norma Técnica Colombiana "Películas de celulosa regenerada. Determinación de la permeabilidad al vapor de agua".

[18] M. I. Khalil, A., Hashem and A. Hebeish, "Preparation and characterization of starchacetate",Starch-Stärke, vol. 47, no. 10, pp. 394$398,1995$.

[19] A. Gunaratne and H. Corke, "Influence of prior acid treatment on acetylation of wheat, potato and maize starches",Food chemistry, vol. 105 , no. 3, pp. 917-925, 2007.

[20] S. Pietrzyk, T. Fortuna, M. Łabanowska, L. Juszczak, D. Gałkowska, M. Bączkowicz and M. Kurdziel, "The effect of amylose content and level of oxidation on the structural changes of acetylated corn starch and generation of free radicals",Food Chemistry, vol. 240, pp. 259-267, 2018

[21] M. Pereda, G. Amica andN. E. Marcovich, "Development and characterization of edible chitosan/olive oil emulsion films",Carbohydrate Polymers, vol. 87, no. 2, pp. 1318-1325, 2012.

[22] R. E. González-Cuello, J. Pérez-Mendoza andL. A. García-Zapateiro, "Efecto de la Adición de Goma Gelana sobre las Propiedades de Barrera y Físico Mecánicas de Biopelículas Binarias”,Información tecnológica, vol. 28, no. 1, pp. 143-150, 2017.

[23] J. Krochta and C. Mulder, "Biodegradable Polymers from Agricultural Products", Food Science and Technology.Vol. 647, pp. 120$140,1996$.

[24] R. D. Baron, L. L. Pérez, J. M. Salcedo, L. P. Córdoba andP. J. Do AmaralSobral, "Production and characterization of films based on blends of chitosan from blue crab (Callinectessapidus) waste and pectin from Orange (Citrus sinensisOsbeck) peel", International Journal of Biological Macromolecules, vol. 98, pp. 676-683, 2017.

[25] S. Garg and A. K. Jana, "Characterization and evaluation of acylated starch with different acyl groups and degrees of substitution",Carbohydrate Polymers, vol. 83, no. 4, pp. 1623-1630, 2011.

[26] L. Fuentes, R. E. González andJ. Pérez, "Cambio en las propiedades físico-mecánicas de biopelículas a base de gelana de bajo acilo",Agronomía Colombiana, vol. 34(1Supl), pp. S80-S82, 2016.

[27] J. J. Kester and O. R. Fennema, "Edible films and coatings: a review",Food technology (USA). 1986. 